van Bonaventura die de vrouw heel wat mecr recht doet (blz. 77). Deze meer waarderende houding sluit goed aan bij de twaalfde-eeuwse mentaliteit die uitgetekend wordt door figuren als Bernard van Clairvaux en Abelard.

Over het algemeen kan men Bots interpretaties terecht noemen. Zelden geven ze aanleiding tot fundamentele aanmerkingen. Toch twee kanttekeningen.

Als voorbeeld van de constructieve houding van Bernard van Clairvaux, verwijst de auteur naar een fragment van een brief die de abt naar gravin Ermengard schreef. Een mooi stukje epistolaire stijl, zeker en vast. Maar waarom Bot voor deze periode, in alle talen zwijgt over de bekende brief die Petrus Venerabilis, abt van Cluny, na de dood van Abelard aan Heloïse schreef, blijft een raadsel. De achting en eerbied voor de vrouw Heloïse die hieruit blijkt, is een van de treffendste illustraties van Bots eigen interpretatie van de twaalfde eeuw.

In een ander, meer fundamenteel verband, had men vervolgens ook kunnen wensen dat het hele rationaliseringsproces, door Bot zelf terecht "een diep in de geschiedenis ingrijpende culturele ontwikkeling" genoemd, wat meer onderbouwd was geworden.

Deze enkele bedenkingen nemen evenwel niet weg dat het hier gaat over een vlot geschreven en degelijk uitgewerkte studie, wars van elk zwart-wit denken dat maar al te vaak de behandeling van deze thematiek ontsiert.

Raoul BAUER

\title{
EEN EENZAME KONINGIN
}

Hella S. Haasse en S.W. Jackman, Een vreemdelinge in Den Haag, Amsterdam-Antwerpen, Veen, 1991, 282 blz. ISBN 902042037

De Wurttembergse prinses Sophie (1818 - 1877) huwt op éénentwintigjarige leeftijd met Willem van Oranje, de erfprins der Nederlanden, en is vanaf 1849 koningin. Gedurende vijfendertig jaar onderhoudt zij een vaak intense briefwisseling met Lady Malet, de vrouw van een Engelse diplomaat. Van deze correspondentie zijn alleen de brieven van Sophie bewaard gebleven. Een selectie hiervan heeft de Canadese hoogleraar S.W. Jackman uitgegeven en heeft Hella S. Haasse vertaald en bewerkt. Het resultaat is niet enkel cen vlot leesbare tekst, maar ook, bekeken vanuit het standpunt van de historische relevantie, een interessante bronnenuitgave.

De vreemdelinge in Den Haag is vooreerst een intelligente persoonlijkheid. Opgevoed in een voor die tijd vrij 'liberale' sfeer, heeft zij contact met toonaangevende wetenschappers en schrijvers zoals H. Schliemann, Macauley, von Ranke, Motley, Renan en Guizot. Diezelfde openheid van geest vinden we ook in haar lectuur. Zo kan men in de hier opgenomen brieven een welliswaar te korte maar niettemin merkwaardige verwijzing naar Stendhals Le rouge et le noir aantreffen. 
Vervolgens is zij door nauwe of verre familiebanden met alle Europese vorstenhuizen verbonden. De contacten die zij hiermee onderhoudt zijn vrij levendig en geven een vaak goed beeld van de tijdsproblematiek. Volgens von Ranke is zij "zo geheel en al op de hoogte van alle tijdsvragen, van alle toestanden der volkeren, van alle verwikkelingen en kwesties der kabinetten" dat hij haar niet heeft kunnen vertellen wat "haar vreemd of nieuw was". De coryfee van de Duitse historici is van oordeel dat zij "een Europees leven leefde, een echte kosmopoliet was". Een voorbeeld van haar politieke belangstelling en inzicht is haar kritische vraag aan haar neef Napoleon over de draagwijdte van een 'plan' om Belgiè binnen te vallen.

In een periode waarin het Europese continent in volle gisting lijkt (Krimoorlog, het éénwordingsproces van Italië en Duitsland, het keizerrijk in Frankrijk...) had zij inderdaad voluit een bevoorrechte getuige kunnen zijn waarvan de geschriften een waardevolle achtergrondinformatie hadden kunnen bevatten. Evenwel, door de gebrouilleerde relatie met haar man, koning Willem III, leeft zij in Den Haag vaak zozeer geïsoleerd, dat in tegenstelling tot Rankes mening, zij niet steeds op de hoogte is van de actualiteit.

Ondanks de bovenstaande bedenking blijven haar brieven als historische bron de moeite waard. Wel is het jammer dat de annotaties zo spaarzaam zijn aangebracht dat bepaalde beschreven gebeurtenissen of personages voor de lezer onduidelijk blijven. De algemene inleidingen bij elk deel en de genealogische overzichten achteraan het boek, vullen deze leemte niet op.

Raoul BAUER

\section{EXTIMITEIT ?}

M.L. van Thiel, Binnenste buiten. Psychoanalytische essays over de verhouding tussen buiten- en binnenwereld, Meppel/Amsterdam, Boom \& Deurne, Denis 1991, 117 blz., 550 Fr. ISBN 9060099958

Een kleine sinaasappel - even dacht ik aan een mandarijn, maar kleur en zichtbare consistentie van de schil evenals proporties van de vrucht overtuigden mij, bij gebrek aan geur en tast, van het tegendeel - siert de mooie, sobere omslag van dit bundel essays. Als bloembladen opengeplooid laat de in vieren gesneden schil de samengesloten partjes van de vrucht zien.

Essays van de hand van psychoanalytici. In het Nederlands. En met een lichtjes kryptische titel. Wat kan een mens dezer dagen meer verlangen ? Het DSM-tijdperk bevordert immers niet zo dadelijk de reflexieve benadering of de bedachtzame theorievorming in het 'psy'-vakgebied. Misschien daarom de gedachte aan een uitroepteken bij de titel die men dan meteen (van Dale maakt geen bezwaar) voor de slagkracht in één woord zou schrijven: 'Binnenstebuiten !'. Bij nader beschouwing dan toch maar geen 